\title{
Intellectual property
}

\section{Making fair dealing fairer in Australia? by Fiona Macmillan}

In September 1998 the Copyright Law Review Committee (CLRC), the Australian Government's advisory body on copyright law issues, handed down its report entitled Simplification of the Copyright Act 1988 (Commonwealth of Australia, 1998). The CLRC's terms of reference for this report required it to consider the simplification of those parts of the Copyright Act 1968 (Cth) dealing with exceptions to the exclusive rights conferred on copyright holders 'to make it able to be understood by people needing to understand their rights and obligations under the Act' (CLRC Terms of Reference, December 1996, para. 1(a)). As would be expected, the fair dealing exceptions, which are a centrepiece of the law in this area, are given thorough treatment by the CLRC Report. The CLRC's recommendations in relation to these exceptions are the focus of this article.

There are a number of important issues arising from the legal and policy environment which inevitably affect any attempt to reform the law on fair dealing. Many of these are mentioned, expressly or by implication, in the CLRC's terms of reference. One such matter, which also received star billing in the terms of reference, relates to the international obligations of Australia as a signatory or likely signatory to a variety of multilateral treaties. Other interconnected issues of concern in formulating reform proposals include the desirability of consistency with other significant common law jurisdictions, the demands of the digital environment and the removal of anomalies and unworkable provisions in the present legislation. Underlying all of these issues is the need to articulate with some reasonable precision the aims and rationale of the fair dealing exceptions.

\section{AIMS AND RATIONALE OF FAIR DEALING LAW}

Bearing in mind the central role of the fair dealing exceptions in tempering the extent of the exclusive rights of a copyright holder, it is difficult to articulate a rationale for fair dealing law without fitting it into some more general rationale for copyright law itself. It seems to be accepted amongst scholars that at base copyright law is attempting to effect a balance between the owners of copyright material and those who wish to use that material. The question is how to effect that balance and to what ends. The CLRC Report (para. 5.08ff) draws a distinction between two approaches which were canvassed in the case of American Geophysical Union $v$ Texaco Inc (1994) 29 LPR 381. One of these approaches is to regard copyright law as a vehicle for securing 'maximum economic return' for copyright owners The other approach, embraced by Judge Jacobs, is to:

'[assure] the author of a fair return, while permitting creative uses which build upon the author's work'.

Without a great deal of explanation the CLRC has concluded in its Report (para. 5.10) that the second of the two approaches is more consistent with the justification for Australian fair dealing law. One useful consequence of embracing the approach of Judge Jacobs, as noted above, is that it allows the articulation of a distinction between productive and reproductive uses of another's copyright work (see the CLRC Report, para. $5.11 \mathrm{ff}$, and Campbell $v$ AcuffRose Music Inc (1994) 114 S Ct 1164). The former concerns a creative use of existing copyright work, whilst the latter involves a merely exploitative use of someone else's intellectual property. This is a useful distinction to draw when formulating the basis of fair dealing law. The distinction fits in with a frequently cited rationale for copyright law, which involves the encouragement of creativity in certain designated areas (see, e.g. the Preface to the World Intellectual Property Organisation's Guide to the Berne Convention for the Protection of Literary and Artistic Works (WIPO Publication No 615 (E), 1978).

However, there are some serious limitations in the way in which the CLRC has approached the question of aims and rationales. At the broadest level, it does nothing to address frequently-expressed concerns that the encouragement of creativity as a rationale for copyright law fails adequately to explain the modern content and operation of copyright law (see, e.g. F Macmillan Patfield, 'Legal Policy and the Limits of Literary Copyright' in P Parrinder and W Chemaik (eds), Textual Monopolies: Literary Copyright and the Public Domain (1997)). More specifically, with respect to the fair dealing exceptions, it gives only the most limited guidance on how to formulate the relevant law. The CLRC Report states that its approach to the rationale of fair dealing law is consistent with the Berne Convention (para. 5.10). It notes that in the negotiations leading up to that convention it was agreed that:

'limits to absolute protection are rightly set by the public interest'. (CLRC Report, para. 5.10, quoting Actes 1884, 67; emphasis added)

This, it seems, is the real nub of the matter. The big question is this: what particular aspects of the public interest have sufficient force to outweigh the interests of copyright owners? Are we just talking about the public interest in encouraging creativity, or are there also other aspects of the public interest that fair dealing law ought to be recognising? In particular, it does not seem unreasonable to ask whether fair dealing law should have any contribution to make when the values of copyright law come face to face with other significant sociolegal values, such as those attending the concepts of freedom of speech and freedom of information (see, e.g. J Waldron, 'From Authors to Copiers: Individual Rights and Social Values in Intellectual Property' (1993) 68 ChicagoKent Law Review 841; and F Macmillan Patfield, 'Towards a Reconciliation of Free Speech and Copyright' in E Barendt et al (eds), The Yearbook of Media and Entertainment Law 1996 (Clarendon Press, 1996), 199, esp. 226-232). Due to the rarefication of the relevant multilateral treaties, these issues are skipped around at the international level. Nevertheless 
they seem important enough to be addressed at the national level at least, and some more detailed assessment of them would have been a welcome addition to the CLRC's Report.

\section{INTERNATIONAL OBLIGATIONS}

Whilst the various multilateral treaties do not provide much specific guidance in divining the rationale of the fair dealing exception, they do provide general guidelines within which the Australian legislature is obliged to confine itself. Currently, the two major sourçes of relevant international treaty obligation are the Berne Convention for the Protection of Literary and Artistic Works and the GATT Trade Related Aspects of Intellectual Property Agreement (the TRIPs Agreement). The other existing treaty obligations of relevance to the task of the CLRC are those which arise under the Rome Convention for the Protection of Performers, Producers of Phonograms and Broadcasting Organisations. In addition to working within the confines of these treaties, the CLRC was also required by the terms of reference to consider the implications of its reconmendations with respect to the two new kids on the block, the WIPO Copyright Treaty (WCT) and the WIPO Performances and Phonograms Treaty. Neither of these two treaties is yet in force and the Australian government has not yet signed the treaties, nor has it indicated whether it will do so. However, it seems sensible to keep the option to do so open.

The Berne Convention contains a number of permitted exceptions from the exclusive rights which its grants to copyright holders (see Berne Convention art. 9(2), 10, 10bis and 14bis(2)(b)). These provisions are more narrowly based than the so-called three-step test in art. 13 of the TRIPs Agreement. Article 13 provides:

'Members shall confine limitations or exceptions to exclusive rights to certain special cases which do not conflict with a normal exploitation of the work and do not unreasonably prejudice the legitimate interests of the right holder.'

The CLRC Report concludes (para. 111 and 112), consistently with the results of a study by the WIPO International Bureau (see WIPO International Bureau, Implications of the
TRIPs Agreement on Treaties Administered by WIPO (WIPO Publication No 464(E), 1996, para. 52 and 53), that the exceptions permitted under the Berne Convention do not conflict with art. 13 of the TRIPs Agreement (see also M Blakeney, Trade Related Aspects of Intellectual Property Rights, Sweet \& Maxwell, 1997).

The Berne Convention also employs the three-step test with respect to the exclusive right of reproduction in relation to literary and artistic works (art. 9(2)). Its more specific exceptions deal with the making of quotations from published works (art. 10(1)), the use of literary and artistic works in the educational context (art. 10(2)), and the use of certain copyright works in newspapers or broadcasts for the purpose of reporting the news (art. 10bis). So far as the WCT is concerned, its art. 10 substantively duplicates the three-step test in the TRIPs Agreement both with respect to the rights granted under the Treaty itself and with respect to the application of the Berne Convention.

\section{CONSISTENCY WITH OTHER JURISDICTIONS}

Appendix C of the CLRC Report contains a useful and interesting review of the law governing exceptions to the exclusive rights of copyright holders in a number of jurisdictions. It is evident, however, that in relation to its recommendations on the fair dealing exceptions, the CLRC placed primary emphasis on the comparable provision in the US.

Of the jurisdictions surveyed by the CLRC, the US fair use law (US Copyright Act 1976, s. 107) was the only one to embrace what the CLRC described as 'an open-ended fair use scheme', as opposed to 'a closed set' of exceptions for specific purposes (CLRC Report, para. 3.03). The CLRC embraced this aspect of the US model in its major recommendation that Australian law move from its present closed set of exceptions to an openended scheme (see para. 6.10ff). One interesting aspect of this recommendation is the assertion in the CLRC Report (para. 6.14) that an openended scheme, which does not explicitly limit the purposes in relation to which fair dealing may take place, is in compliance with the three-step test in the Trips Agreement and the Berne Convention. In fact, the Report does not argue this point with much vigour, but rather takes the pragmatic line that as the US open-ended fair use scheme has not been challenged under the TRIPs Agreement or the Berne Convention, such schemes can be taken to be in compliance with the three-step test.

\section{THE CLRC PROPOSALS}

At present the fair dealing exceptions in Australia only apply with respect to the use of copyright material for four purposes. These purposes are research or study, criticism or review, reporting of the news, and the giving of professional advice by a legal practitioner or patent attorney. The application of the section is complicated by the fact that the Australian Copyright Act, rather eccentrically, divides copyright works into two different categories. Complications also arise from ambiguities and anomalies which have not yet been clarified by legislative intervention.

\section{Consolidation of provisions}

The Australian Copyright Act protects, in its Part III, copyright items which it describes as 'works' and, in Part IV, 'subject matter other than works'. The relevant distinction here is between the traditional categories of literary, dramatic, musical and artistic works, on the one hand, and sound recordings, films, broadcasts and published editions, on the other. As a result of this distinction, the fair dealing provisions with respect to research or study, criticism or review, and reporting the news are repeated, with some differences in language, for Part III works and for audio-visual items (sound recordings, films and broadcasts) within Part IV. The fair dealing exception with respect to professional legal advice only applies in relation to literary, dramatic, musical and artistic works.

Apart from being unnecessarily complicated and 'user unfriendly', this division between Part III works and Part IV audio-visual items can cause problems. For example, there appears to be some problem in the crossover between the provisions governing fair dealing with a Part III work for the purpose of criticism or review (s. 41) and fair dealing with a Part IV audio-visual item for the same purpose (s. 103A). For some reason, not obvious on the face of it, fair dealing with a Part III work for the 
purpose of criticism or review of an audio-visual work is not protected, whilst fair dealing with an audio-visual work for the purpose of criticism or review of a Part III work is protected. The CLRC Report proposes removing the Part III/Part IV split in the fair dealing provisions by consolidating this important exception in one provision. The proposed consolidated provision would not only deal with all types of copyright material, it will also open up the category of purposes for which fair dealing may take place (see CLRC Report para. 6.143). The four purposes, described above, to which fair dealing is currently limited are referred to in the proposed provision, but only as part of an inclusive list. As mentioned above, this reflects the influence of the US open model.

\section{List of criteria}

A feature of the present legislation is that the sections on Part III and Part IV (s. 40 and s. 103C, respectively) dealing with fair dealing for the purpose of research or study contain an inclusive list of factors to be considered in determining whether or not the dealing in question is fair. These factors resemble, but are not identical to, the list of such factors contained in s. 107 of the US legislation. They are:

- the purpose and character of the dealing;

- the nature of the work;

- the possibility of obtaining the work within a reasonable time at an ordinary commercial price;

- the effect of the dealing upon the potential market for, or value of, the work; and

- where only part of the work is copied, the amount and substantiality of that part in relation to the whole work.

The peculiar thing is that this helpful list is not repeated for any of the other fair dealing exceptions The CLRC proposes to remedy this by making this non-exclusive list relevant to the issue of fairness in relation to any dealing alleged to fall within its proposed composite fair dealing exception.

\section{Quantitative test}

There is one important aspect of current Australian fair dealing law that has no international counterpart. This is the inclusion of what is known as the quantitative test in the current provision governing fair dealing with literary, dramatic and musical works for research and study (see s. 40(3)). This test deems copying of a published work for the purposes of research and study to be fair provided certain quantitative limits are not exceeded. The CLRC Report (para. 6.68) recommends that, as this provision requires no consideration of the general fairness criteria, it be removed from the fair dealing provisions and converted into a 'stand-alone' exception. It also recommends that the new stand-alone quantitative exception be extended to apply to all dealings with literary, dramatic and musical works rather than only dealings by way of copying. The CLRC Report does not consider whether the quantitative test should be extended to dealings for purposes other than research and study. It also does not consider whether the quantitative exception, as opposed to the fair dealing exception, should be limited to research and private study. The CLRC rejected the addition of this qualification, which would mirror the current UK provision (see the Copyright Designs and Patents Act 1988, s. 29), to its proposed fair dealing exception on the ground that the concerns raised could adequately be dealt with on the basis of considerations of fairness (see CLRC Report, para. 6.112-6.117). This logic, however, does not apply to its stand-alone quantitative exception, which is not subject to such considerations.

\section{DIGITAL ISSUES}

In 1998 the Australian government announced that it would be reforming the Copyright Act to introduce a new exclusive right of communication to the public (see The Hon Daryl Williams, 'Copyright and the Internet: New Government Reforms', speech delivered at Murdoch University, 30 April 1998). This is intended to be a technologyneutral right which, amongst other things, would apply to communications which utilise digital technology, such as communications on the Internet. In announcing these reforms, the Attorney General made it clear that the government intended to make this new right subject to fair dealing exceptions. Both the new right of communication to the public and the proposal to make this right subject to fair dealing exceptions are consistent with the terms of the WIPO Copyright Treaty.

Taking these matters into account, as required by its terms of reference, the CLRC Report concludes that making the proposed right of communication to the public subject to its proposed openended fair dealing provision is consistent with both the stated intention of the Australian Government and any obligations that might be assumed under the WIPO Copyright Treaty. Nevertheless, it is clear from the Report that the question of the extension of the proposed fair dealing exception and the proposed quantitative exception to the digital environment was a vigorously contested one.

The ease of copying in the digital environment appears, in the opinion of the CLRC, to be balanced by the new potential for copyright owners to monitor and license the use of their work (CLRC Report, para. 6.18). As a consequence, the majority of the CLRC took the view that this underlines the need for fair dealing exceptions to apply (para. 6.19). The CLRC rejected the submission of the Copyright Agency Limited, a collecting society, that digital copying should fall outside the fair dealing exception and be governed by a voluntary or statutory licence scheme (para. 6.21). It agreed with the submission of the Australian Council of Library and Information Services that it would not be in the public interest to create a market in words and sentences (para. 6.23).

In relation to fair dealing in the digital environment, particular concerns raised by the CLRC Report are whether or not including a work in an electronic database or making a work available in digital form could be regarded as fair dealings.

In both cases the majority of the CLRC took the view that any explicit limitation in its proposed fair dealing provision would unnecessarily limit the flexibility of the provision. Nevertheless the Report recognises that in both these cases the dealing in question may very well be judged to be unfair on the basis of the inclusive list of fairness criteria in its proposed provision (see CLRC Report, para. 6.43 and 6.93 respectively).

The question of the application of the proposed quantitative exception to the 
digital environment was a problematic one for the CLRC. While a number of submissions urged the CLRC to extend this exception to dealings with material available in digital form, the CLRC concluded that the quantitative test would not work in relation to such material and should be confined to copyright material published in print form. The reasons that the CLRC decided to confine the quantitative exception to non-digital printed copyright works were: first, difficulties with identifying discrete units of measurement for works in digital form; secondly, the lack of distinction which may exist between digitised copyright works; and thirdly, concerns that the application of the quantitative exception to dealings with electronic databases would result in the protected copying of large numbers of separate copyright works (see CLRC Report, para. 6.53ff). On the other hand, the majority of the CLRC did recommend that the quantitative exception apply where hard copy copyright material is converted to digital form (para. 6.77). Given the CLRC's recognition of the fact that such copying may well fall outside the criteria for fairness in its proposed fair dealing provision, this recommendation may not be regarded as entirely predictable.

\section{CONCLUSION}

If brought into legislative effect, would the proposals of the CLRC make fair dealing fairer? Certainly, the CLRC proposals have the considerable merit of making the legislation considerably clearer for both owners and users of copyright works. It is difficult to argue with the proposition that fairness is likely to be advanced by such clarification. The proposed fair dealing exception is also more flexible than the present fair dealing law. In terms of fairness, flexibility may be regarded as a twoedged sword. While it enhances the scope of judges to take all relevant considerations into account, some may consider that there are losses in terms of predictability. However, as the proposed provision is substantially based on the existing legislation and well-developed judge-made law it seems unlikely that it will give much scope for undesirable judicial creativity. The main area of development seems likely to be in relation to the principles to be applied in cases involving digital considerations In this area the flexibility of the proposed provision is likely to be a help rather than a hindrance in developing an appropriate jurisprudence.

Ultimately the question of fairness is really one about whether or not the balance between copyright owners and the users of copyright works has been appropriately drawn. The CLRC Report notes (para. 6.34) that copyright owners have generally taken the view that the open-ended provision recommended by the CLRC unreasonably favours copyright users, whereas copyright users support the proposed changes. The real issue, however, is whether the interests of society in general are best served by the balancing of interests proposed by the CLRC. We will not really be in a position to judge this question until we have a more comprehensive analysis of the aims and rationales of copyright law. (c)

Fiona Macmillan

Associate Professor of Law, Murdoch University,

Western Australia; Copyright Director, Asia Pacific Intellectual Property Law Institute

\section{Anti Money Laundering Guide}

Your subscription includes

CD ROM

- Four updates per annum

LOOSE-LEAF

- Single volume

- Four updates per annum

NEWSLETTER

- Money Laundering Monitor

- Monthly issues

\section{SPECIAL OFFER!}

\section{Launch Price $£ 240.50$}

Save $£ 60$ on orders received before July 1999

Normal Price $£ 300.50$
A practical guide to some of the pitfalls involved in handling other people's funds, including an expert examination of money laundering law and practice in the UK and its consequences, as well as a survey of similar prevention laws around the world in key financial jurisdictions.

\section{Topics covered include:}

- The phenomenon of money laundering and the issues involved in handling and advising on other people's wealth

- International anti money laundering initiatives launched to date

- Money laundering law and practice in the UK including prevention, compliance, investigations and whistleblowing

- The money laundering regulations of the major jurisdictions within the world's financial systems 